\title{
CLASSIFICATION OF POLISH CITIES BASED ON ENVIRONMENTAL AND COMMUNICATION CONDITIONS
}

\author{
Jadwiga Zaród \\ West Pomeranian University of Technology in Szczecin, Szczecin, Poland \\ e-mail: jzarod@zut.edu.pl
}

ORCID: 0000-0002-3771-0490

(C) 2020 Jadwiga Zaród

This is an open access article distributed under the Creative Commons Attribution-NonCommercial-NoDerivs license (http://creativecommons.org/licenses/by-nc-nd/3.0/)

DOI: 10.15611/eada.2020.1.02

JEL Classification: C38, O13, Q12

\begin{abstract}
Problems associated with environmental pollution concern most large Polish cities. They are mainly caused by transport, municipal waste, emissions from the housing sector and from factories, particularly burdensome for the environment. Based on data related to the state and the protection of the natural environment and road transport, the author attempted to divide Polish cities with county ('powiat') rights into groups with different environmental features. Discriminatory analysis was used for the division. The highest average value of the discriminatory function was shown by the group with the most favourable environmental and social conditions. In subsequent groups, the environmental pollution grew more and more. In turn, classification functions of discriminatory analysis allowed for the assignment of individual cities to selected groups. Discriminatory analysis could therefore be used as a support tool for examining the state of the environment and environmental protection in cities with county rights. The goal of the work is to identify the diversity of environmental and communication conditions in Polish cities with county ('powiat') rights.
\end{abstract}

Keywords: cities with county rights, environmental pollution, discriminatory analysis.

\section{Introduction}

The problems associated with environmental pollution concern most large Polish cities. They are mainly caused by transport, predominantly motorised, municipal waste, emissions from the municipal and housing sector and industry, which are especially burdensome for the environment. Transport development is an important condition for economic growth, but also a cause of environmental and social problems. Road transport in particular is a source of air pollution with carbon monoxide, nitrogen oxides, hydrocarbons, as well as PM10 and PM2.5 dust (solid particles with a diameter of 10 and $2.5 \mu \mathrm{m}$ respectively) (Badyda and Lubiński, 2009). The 
number of cars is growing by the year, causing not only increased emissions, but also noise pollution. The expansion of the road network cannot keep up with that growth, it causes traffic jams to develop, blocking the traffic on streets with the highest load, and increasing noise. Noise and vibrations induced by vehicles make a negative impact on the health and mood of the citizens (Colvile, Hutchinson, Mindell, and Warren 2001).

Municipal waste is also a serious problem of the urban environment. Its upward trend, with the frequent lack of comprehensive technical and organizational solutions, leads to the pollution of air, soil, and surface waters, as well as contamination by industry. Waste from heavy industrial plants, located at city boarders, is especially dangerous (Onder, Dursun, Gezgin, and Demirbas 2007). The rational management of municipal waste requires waste segregation, its selective gathering and neutralization, as well as, if possible, recovery or recycling (Guerrero, Maas, and Hogland, 2013; Kukuła, 2016).

Emissions from the municipal and household sector are an important source, worsening the quality of air in cities during winter. During the heating season, they contribute to the creation of the smog phenomenon, especially in cities of southern Poland (GIOŚ 2017).

In such conditions, urban greenery (parks, gardens, lawns, housing estate greenery, street greenery) does not perform only recreational function. Properly located, it helps combat air pollution (McDonald et al., 2007) and excessive noise present in cities, and supports fresh air circulation arriving from suburban areas. It also provides natural protection from wind. It regulates air humidity and reduces temperature in cities during the summer months (Chojecka, 2014).

Unfortunately, the size of urban greenery areas in recent years has been slowly but systematically decreasing due to them being subject to residential and service development, as well as the liberalization of provisions regulating the removal of trees and shrubs (Nawrotek, 2017). Moreover, the loss of greenery in cities is contributed to by polluted air and the lowering level of groundwater (due to drainage and construction development). Only regular planting of trees and shrubs, and planning spatial development accounting for urban greenery will ensure the growth of green areas in cities.

Knowledge of the state of the natural environment, and the communal and transport problems in cities might contribute to undertaking ecological and investment actions. Discriminatory analysis might be a tool assisting with the recognition of these problems. Diagnostic variables related to transport, emissions of pollutants, waste and urban greenery will be used in this work for the division of cities with county rights into groups differing by the selected features. Cities with county rights are local government units in Poland, fulfilling the tasks of both municipality and county. These tasks include, among others:

- urban roads, streets, bridges, squares and traffic organizations;

- $\quad$ public transport and public roads; 
- protection of the environment and nature;

- water supply, sewerage, disposal and treatment of municipal wastewater, landfills and the disposal of municipal waste.

The listed tasks were the deciding factor in choosing the cities with county rights as subjects to study.

The goal of this article is to identify the varied natural and environmental, as well as communication conditions in Polish cities with county rights. The research hypothesis is that the development of public transport and municipal problems in cities unfavorably affect the natural environment.

\section{Research material - selection of diagnostic variables}

The empirical data for the study is provided by the local data bank of the Central Statistical Office (GUS, 2017) and by the metering data bank of the Chief Inspectorate for Environmental Protection (GIOŚ, 2017) for the year 2017. The gathered information on all Polish cities with county rights (number of cities $n=66$ ), after their modification, constitutes a set of diagnostic variables (Table 1).

Table 1. Set of diagnostic variables

\begin{tabular}{|c|l|l|}
\hline Variables & \multicolumn{1}{|c|}{ Name of the variable } & \multicolumn{1}{c|}{ Unit } \\
\hline$x_{1}$ & (area of walking and recreation parks/city area) $\times 100$ & $\%$ \\
\hline$x_{2}$ & (area of lawns/city area) $\times 100$ & $\%$ \\
\hline$x_{3}$ & (area of street greenery/city area) $\times 100$ & $\%$ \\
\hline$x_{4}$ & (area of housing estate greenery/city area) $\times 100$ & $\%$ \\
\hline$x_{5}$ & (area of parks, lawns and housing estate greenery/city area) $\times 100$ & $\%$ \\
\hline$x_{6}$ & planting of trees/city area & $\mathrm{pcs} \times \mathrm{km}^{-2}$ \\
\hline$x_{7}$ & planting of shrubs/city area & $\mathrm{pcs} \times \mathrm{km}^{-2}$ \\
\hline$x_{8}$ & (areas legally protected in total/city area) $\times 100$ & $\%$ \\
\hline$x_{9}$ & (people using sewage treatment plants/city area) $\times 100$ & $\%$ \\
\hline$x_{10}$ & municipal waste/number of inhabitants & $\mathrm{kg} \times(\mathrm{person})^{-1}$ \\
\hline$x_{11}$ & other wastes accumulated in total/number of inhabitants & $\mathrm{t} \times(\mathrm{person})^{-1}$ \\
\hline$x_{12}$ & treated municipal waste per km of city area & $\mathrm{dam}$ \\
\hline$x_{13}$ & gas pollution emission from onerous plants/city area & $\mathrm{t} \times \mathrm{km}^{-2}$ \\
\hline$x_{14}$ & dust pollution emission from onerous plants/city area & $\mathrm{t} \times \mathrm{km}^{-2}$ \\
\hline$x_{15}$ & length of hard surface public roads/city area & $\mathrm{km} \times \mathrm{km}^{-2}=1 \times \mathrm{km}^{-1}$ \\
\hline$x_{16}$ & length of hard surface public roads/number of inhabitants & $\mathrm{km} \times(\mathrm{person})^{-1}$ \\
\hline$x_{17}$ & number of vehicles/number of inhabitants & $\mathrm{pcs} \times(\mathrm{person})^{-1}$ \\
\hline$x_{18}$ & mean weighted intensity of vehicle traffic & $\mathrm{pcs} \times \mathrm{h}^{-1}$ \\
\hline$x_{19}$ & length of bicycle paths/city area & $\mathrm{km} \times \mathrm{km}^{-2}=1 \times \mathrm{km}^{-1}$ \\
\hline$x_{20}$ & pollution of air with PM10 fine particles $(\mathrm{up}$ to $10 \mu \mathrm{m}$ in diameter) & $\mu \times \mathrm{m}^{-3}$ \\
\hline
\end{tabular}

Source: own work. 
Correlation coefficients were calculated between the variables. All strongly correlated variables are excluded from the analysis during testing their discriminatory power by the Statistica program (Internetowy Podręcznik Statystyki).

The values of diagnostic variables underwent standardization in order to make the analysis results independent of the measurement units of individual variables (Jajuga and Walesiak, 2000) using the formula:

$$
z_{i j}=\frac{x_{i j}-\bar{x}}{s} \quad \text { for } i=1,2, \ldots, n j=1,2, \ldots, m,
$$

where: $x_{i j}$ - the value of $j$-th variable for $i$-th cities, $\bar{x}$ - the mean value of a given variable, $s$ - standard deviation.

Some variables $\left(x_{10}, x_{11}, x_{13}, x_{14}, x_{17}, x_{18}, x_{20}\right)$ are destimulants, and by multiplying their values by minus one they were transformed into stimulants.

The number of groups $(k)$ into which cities with 'powiat' rights were divided was determined on the basis of the Celiński-Harabasz index:

$$
C H(k)=\frac{B k(k-1)}{W k(n-k)}
$$

where: $B k$ - intergroup covariance matrix, $W k$ - intragroup covariance matrix, $k$ - number of classes, $n$ - number of objects (66 cities).

The highest values of the $\mathrm{CH}$ index (Walesiak, 2013) decided the division of cities into four groups.

The initial allocation of cities into individual groups was obtained by means of the k-means method (Sobolewski and Sokołowski, 2017) based on all variables.

The assumptions of discriminant analysis (Hubert and Driessen, 2004) show that the data (captured as diagnostic data) should represent a sample from multidimensional normal distribution. Variables with a normal distribution for further analyses were selected by means of the Kolmogorov-Smirnov test (Krzyśko, 2004) (Table 2).

A test probability greater than the relevancy level $\alpha=0.05$ demonstrated the lack of basis for rejecting the normal distribution compatibility hypothesis.
Table 2. Normal distribution test

\begin{tabular}{|c|c|c|}
\hline \multirow{2}{*}{$\begin{array}{c}\text { Variables } \\
\text { with a normal } \\
\text { distribution }\end{array}$} & \multicolumn{2}{|l|}{ Kolmogorov-Smirnov test } \\
\cline { 2 - 3 } & $\mathrm{D}$ & $\mathrm{P}$ \\
\hline$x_{3}$ & 0.1209 & 0.2671 \\
\hline$x_{4}$ & 0.0959 & 0.5455 \\
\hline$x_{5}$ & 0.0958 & 0.1494 \\
\hline$x_{9}$ & 0.1609 & 0.0583 \\
\hline $\mathrm{x}_{10}$ & 0.1319 & 0.1841 \\
\hline $\mathrm{x}_{12}$ & 0.0867 & 0.6718 \\
\hline $\mathrm{x}_{13}$ & 0.1063 & 0.0932 \\
\hline$x_{15}$ & 0.0763 & 0.8093 \\
\hline$x_{16}$ & 0.1468 & 0.1048 \\
\hline$x_{17}$ & 0.1061 & 0.4186 \\
\hline$x_{19}$ & 0.1077 & 0.4000 \\
\hline$x_{20}$ & 0.0790 & 0.7706 \\
\hline
\end{tabular}

where: $\mathrm{D}$ - test values, $\mathrm{p}$ - test probability of normal distribution compatibility

Source: own work using the Statistica program. 
Further limitation of the list of variables was caused by the study of their discriminatory power (Gatnar, 2013) by means of tests, Wilks' lambda and F (Table 3).

Table 3. Variables with high discriminative power

\begin{tabular}{|c|c|c|c|c|c|}
\hline Variables & $\begin{array}{c}\text { Wilks' } \\
\text { lambda }\end{array}$ & $F$ & $p$ & Tolerance & $\begin{array}{c}\text { 1-Tolerance } \\
(R \text { squared })\end{array}$ \\
\hline$x_{5}$ & 0.0208 & 3.2300 & 0.0288 & 0.7484 & 0.2516 \\
\hline$x_{10}$ & 0.0232 & 5.8598 & 0.0014 & 0.8553 & 0.1446 \\
\hline$x_{13}$ & 0.1290 & 120.7563 & 0.0000 & 0.7055 & 0.2945 \\
\hline$x_{19}$ & 0.0494 & 34.2979 & 0.0000 & 0.7201 & 0.2798 \\
\hline$x_{20}$ & 0.0308 & 14.0803 & 0.0000 & 0.7343 & 0.2657 \\
\hline
\end{tabular}

Source: own work using the Statistica program.

The Wilks' lambda coefficients demonstrate the high discriminatory power of variables as confirmed by $p \cong 0$ test probability. The greatest contribution to discrimination (the highest values of $\mathrm{F}$ statistics) of groups is made by the $x_{13}$ and $x_{19}$ variables.

A tolerance value above 0.7 indicates that the variables are not strongly correlated with each other.

\section{Discrimination function}

Diagnostic variables with high discriminatory power were used for estimation of discriminatory functions (Stanisz, 2007). The number of discrimination functions cannot exceed the number of discriminatory variables or the number of groups minus one (depending on which one is lower). Further analyses require the selection of a function with the highest own value and the highest percentile participation in the total intergroup variation. Moreover, the Wilks' lambda test value should be close to zero.

Function in the form of:

$$
\mathrm{F}=0.4461 x_{5}-0.3164 x_{10}+1.1073 x_{13}-0.5642 x_{19}-0.4441 x_{20}
$$

explains $77.49 \%$ of intergroup variation, its own value (9.5029) is the highest and has the lowest Wilks' lambda test value (0.0178). The standardized coefficients of the discrimination function indicate the strength of the impact of a given discriminatory variables on group differentiation. The greater their absolute value, the stronger the discriminatory influence of a given variable. The greatest impact on shaping of the assumed function's value is made by the $x_{13}$ and $x_{19}$ variables. Based on this function, canonical values were established (discrimination function values) for each city and on average for each group. The average values of the discrimination function for groups were: I - 2.5905, II - 1.0267, III - (-1.3277), IV - (-8.2872). 
The highest average discriminatory value function showed a group with the most favorable conditions: communication, natural and social. With the decrease in average canonical values, conditions worsened. The discrimination function allowed to create groups that differ from each other due to selected features and rank them.

\section{Classification functions}

The classification functions of discriminatory analysis are used for deciding which group a given case is most likely to belong to. Their number is equal to the amount of groups. Table 4 shows the coefficients of classification functions for all groups.

Table 4. Classification functions for four groups

\begin{tabular}{|c|c|c|c|c|}
\hline \multirow{2}{*}{ Variables } & \multicolumn{4}{|c|}{ Groups } \\
\cline { 2 - 5 } & I & II & III & IV \\
\hline$x_{5}$ & -0.6866 & -0.3252 & -0.0568 & 1.121 \\
\hline$x_{10}$ & -0.2088 & -0.1917 & -0.2330 & -0.269 \\
\hline$x_{13}$ & -0.0005 & -0.0005 & -0.0008 & -0.002 \\
\hline$x_{19}$ & 49.9510 & 28.8202 & 26.6299 & 12.967 \\
\hline$x_{20}$ & -1.7288 & -1.6544 & -2.1776 & -2.393 \\
\hline Constant & -78.8212 & -58.2165 & -91.1715 & -151.479 \\
\hline
\end{tabular}

Source: own work using the Statistica program.

The higher the absolute value of coefficients standing by the variables, the higher the influence of these variable on the creation of classification functions and classification of a given city to the right group. The final division of cities was largely influenced by variables related to the number of bicycle paths $\left(x_{19}\right)$ and air pollution with dust particles PM10 $\left(x_{20}\right)$.

For each city with county rights, the values of all classification functions were calculated. Next, they were assigned to groups for which they reached the highest classification function value.

\section{Results and discussion}

Table 5 presents each analyzed city's final assignment to the right group. The greatest influence on the classification of distinguished groups was made by variables related to bicycle paths and air pollution with dust particles PM10.

There are few bicycle paths in most cities with county rights. This is confirmed by local government reports (Nowak, 2016) which add that bicycle infrastructure in cities is expanding by the year. Saghapour, Moridpour and Thompson (2017) also 
Table 5. List of cities in groups

\begin{tabular}{|c|c|l|}
\hline Groups & $\begin{array}{c}\text { The number } \\
\text { of cities in groups }\end{array}$ & \multicolumn{1}{c|}{ Cities with county rights } \\
\hline I & 18 & $\begin{array}{l}\text { Leszno, Zamość, Sopot, , Rzeszów, Suwałki, Grudziądz, Siedlce, Lu- } \\
\text { blin, Lomża, Słupsk, Torun, Przemyśl, Opole, Białystok, Olsztyn, Wro- } \\
\text { cław, Tarnów, Warszawa }\end{array}$ \\
\hline II & 25 & $\begin{array}{l}\text { Piotrków Trybunalski, Kalisz, Krosno, Bielsko Biała, Biała Podlaska, } \\
\text { Skierniewice, Jelenia Góra, Nowy Sącz, Tarnobrzeg, Koszalin, Radom, } \\
\text { Kielce, Bytom, Elbląg, Bydgoszcz, Wałbrzych, Gdynia, Szczecin, Zie- } \\
\text { lona Góra, Gorzów Wielkopolski, Lódź, Poznań, Swinoujście, Gdańsk, } \\
\text { Włocławek }\end{array}$ \\
\hline III & 17 & $\begin{array}{l}\text { Świętochłowice, Jastrzębie- Zdrój, Mysłowice, Żory, Zabrze, Tychy, } \\
\text { Siemianowice Śląskie, Piekary Śląskie, Ruda Śląska, Sosnowiec, Gliwi- } \\
\text { ce, Legnica, Częstochowa, Katowice, Kraków, Chełm, Jaworzno }\end{array}$ \\
\hline IV & 6 & Dąbrowa Górnicza, Chorzów, Rybnik, Płock, Ostrołęka, Konin \\
\hline
\end{tabular}

Source: own study using the Statistica program.

dealt with the measurement of cycling accessibility in cities. For comparative reasons, the length of bicycle paths in each city was converted to its area. The highest number of bicycle paths per $1 \mathrm{~m}^{2}$ was in Leszno $\left(1.501 \times \mathrm{km}^{-1}\right)$, Rzeszów $\left(1.281 \times \mathrm{km}^{-1}\right)$ and Sopot $\left(1.191 \times \mathrm{km}^{-1}\right)$, cities in group I, whereas the lowest number was reported in Mysłowice $\left(0.0141 \times \mathrm{km}^{-1}\right)$ and Dąbrowa Górnicza $\left(0.0321 \times \mathrm{km}^{-1}\right)$, cities classified to groups III and IV respectively.

Figure 1 shows the sections in which the length of bicycle paths per $1 \mathrm{~km}^{2}$ of the area of cities belonging to the respective groups and their average values were located.

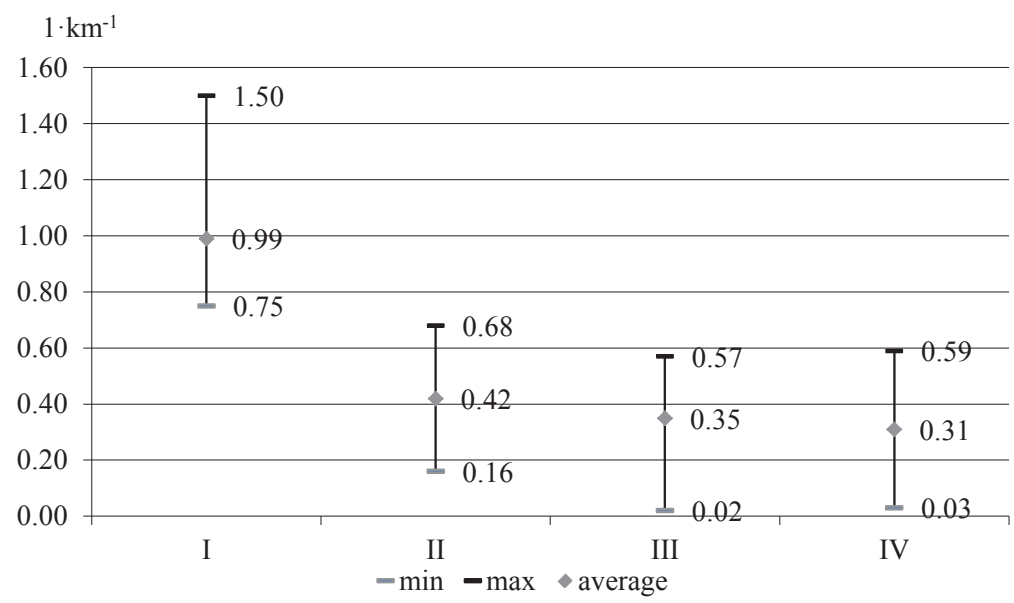

Fig. 1. Length of bicycle paths

Source: own study. 
The inhabitants of most Polish cities are at risk of exposure to the effects of air pollution. According to the WHO guidelines, the maximum level of pollution with PM10 particles acceptable for health is $20 \mu \mathrm{g} \times \mathrm{m}^{-3}$ on yearly average. Out of the 65 Polish cities examined by the World Health Organization in 2016, only six were within the norm (WHO, 2016). The yearly average level of PM10 particles allowed in Poland is the same as in the European Union and equals $40 \mu \mathrm{g} \times \mathrm{m}^{-3}$ (GIOŚ, 2016).

Figure 2 presents the fluctuations of PM10 particle emissions and their mean level in individual groups of cities in 2017 according to State Environmental Monitoring.

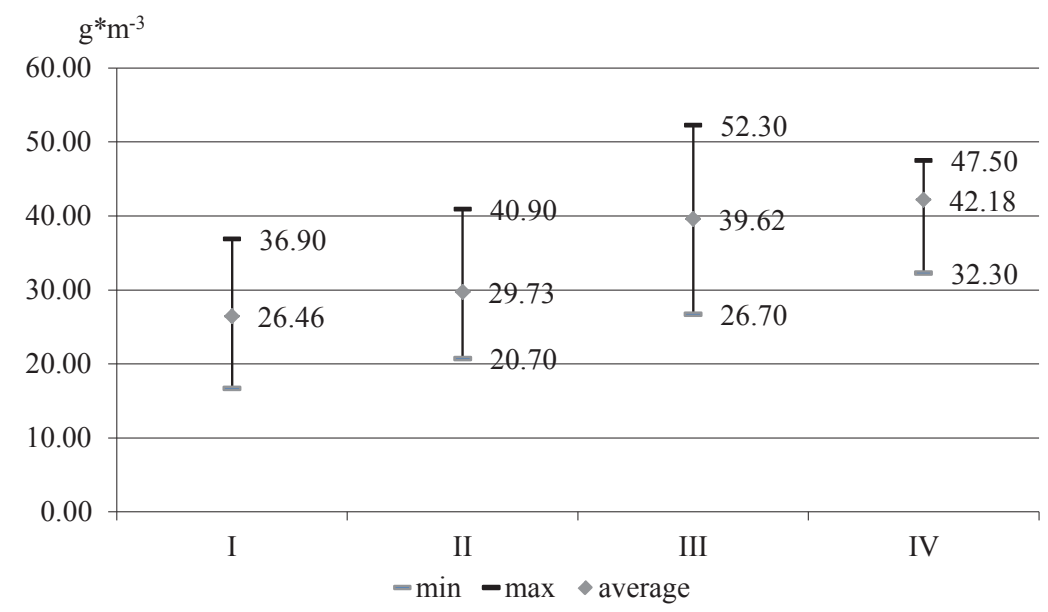

Fig. 2. Air pollution with PM10 particles

Source: own study.

The lowest yearly average air pollution with PM10 particles was reported in: Sopot $\left(16.7 \mu \times \mathrm{m}^{-3}\right)$, Gdynia $\left(18.1 \mu \times \mathrm{m}^{-3}\right)$, Słupsk $\left(19.2 \mu \times \mathrm{m}^{-3}\right)$, Suwałki $\left(19.2 \mu \times \mathrm{m}^{-3}\right)$, Łomża $\left(19.6 \mu \times \mathrm{m}^{-3}\right)$ and Białystok $\left(198 \mu \times \mathrm{m}^{-3}\right)$, cities belonging to group I (except for Gdynia - group II). Air pollution was highest in southern Polish cities. In 12 cities with county rights, the yearly average concentration of PM10 particles in 2016 exceeded the acceptable norms of State Environmental Monitoring. The highest concentration was recorded in Krakow $\left(52.9 \mu \times \mathrm{m}^{-3}\right)$, Rybnik $\left(47.5 \mu \times \mathrm{m}^{-3}\right)$ and Gliwice $\left(46.7 \mu \times \mathrm{m}^{-3}\right)$. In order to reduce the amount of pollution, one has to: introduce new technologies minimizing the use of resources and energy, care for the technical condition of vehicles, re-cultivate degraded environments, increase planting of trees and shrubs, and observe legal provisions related to environmental protection (Hosseinali, Alesheikh, and Nourian 2014).

The number of parks, green areas and estate greenery influenced the classification as well. 
According to UN predictions, $60 \%$ of the world's population in 2025 will live in large urban agglomerations, and $80 \%$ in cities with over 20 thousand inhabitants (GUS 2014). This fact is significant for planning spatial development in cities. These plans have to account for novel, innovative projects related to greenery (BaranZgłobicka and Harasimiuk 2016; Wyrwa 2014; Ong 2003).

The percentage of parks, lawns and housing estate green areas within the general area of cities with county rights in Poland in 2016 was diverse and ranged from about $0.5 \%$ to over $21 \%$. On average, parks, lawns and housing estate green areas constituted $3.75 \%$ of the general area of cities with county rights. Warsaw had 313779 ha of such areas, Łódź 1690.78 ha and Krakow 1673,61 ha. However, the percentage in the general area of cities was the highest in Chorzów (21.21\%), Siemianowice (9.56\%), and Bydgoszcz (7.78\%). The fewest places for recreation and relaxation were for the residents of Świnoujście $(0.55 \%)$, Zielona Góra $(0.72 \%)$ and Piotrków Trybunalski $(0.91 \%)$.

\section{Conclusions}

Discriminatory functions were estimated based on variables with high discriminatory power. The function with the highest intergroup variation allowed for the creation of groups comprising cities with county rights with similar communication, environmental and social conditions. A significant influence on shaping this function's values was made by variables related to: gas emissions from industrial plants especially harmful to the environment, and bicycle routes. The mean values of the discriminatory function for the first two groups were similar, which demonstrates the high similarity of the conditions prevailing in these groups. For the two last groups, that is 3 and 4, the canonical values were significantly different from each other and from other groups. The classification functions of discriminatory analysis, however, allowed for the assignment of individual cities into proper groups. The classification was largely dependent on the length of bicycle paths and air pollution with PM10 particles. Groups I and II included as many as 43 cities with county rights (respectively 18 and 25). Only six cities were classified into group IV.

The performed analyses showed that:

1. There are few bicycle paths in most cities with county rights $\left(0.56 \mathrm{~km}\right.$ per $1 \mathrm{~km}^{2}$ of area on average). The highest number of bicycle paths can be found in cities in group I.

2. Air pollution in many Polish cities exceeds the acceptable norms. This problem relates especially to cities of the Śląskie and Małopolskie voivodeships (concentrated in groups III and IV).

3 . The area of parks, lawns and housing estate green areas in cities with county rights is very diverse. It ranges from $0.55 \%$ to over $21 \%$ of city areas. 
4. Discriminatory analysis can be used as a tool supporting the division of cities with county rights into groups differing in terms of communication, environmental and social conditions.

5. Knowledge of the state of the natural environment state as well as of communal and transport problems in cities may contribute to undertaking ecological and investment actions by local government bodies.

\section{References}

Badyda, A., and Lubiński, W. (2009). The influence of air pollution on pulmonary function test results for people living close to busy roads. Polish Journal of Environmental Studies, 18(3), 7-12.

Baran-Zgłobicka, B., and Harasimiuk, M. (2016). Znaczenie badań geograficznych w poprawie jakości planowania przestrzennego w jednostkach samorządu terytorialnego różnego szczebla. Barometr Regionalny. Analizy i Prognozy, 14(2), 127-140.

Chojecka, A. (2014). Znaczenie terenów zielonych w przestrzeni publicznej oraz ich wpływ na jakość życia miejskiego, Rynek-Społeczeństwo-Kultura, (1), 48-54.

CSO (2014). Prognoza ludności na lata 2014-2050. Pobrano z: https://stat.gov.pl/obszary-tematyczne/ ludnosc/prognoza-ludnosci

CSO (2017). Stan i ochrona środowiska. Pobrano z: https://bdl.stat.gov.pl/BDL/dane/podgrup/temat

Colvile, R. N., Hutchinson, E. J., Mindell, J. S., and Warren, R. F. (2001). The transport sector as a source of air pollution. Atmospheric Environment, 35(9), 1537-1565.

Gatnar, E. (2013). Analiza dyskryminacyjna - stan aktualny i kierunki rozwoju. Studia Ekonomiczne, $152,42-58$.

GIOŚ (2016). Normy dla pytów drobnych w Polsce. Pobrano z: http://www.gios.gov.pl/p1/aktualnosci/294-normy-dla-pylow-drobnych-w-polsce

GIOŚ (2017). Ocena jakości powietrza. Pobrano z: http://powietrze.gios.gov.pl/pjp/home

Guerrero, L. A., Maas, G., and Hogland, W. (2013). Solid waste management challenges for cities in developing countries. Waste Management, 33(1), 220-232.

Hosseinali, F., Alesheikh, A., and Nourian, F. (2014). Rapid Urban Growth in the Qazvin Region and Its Environmental Hazards: Implementing an Agent-Based Model. Pol. J. Environ. Stud., 23(3), 727-735.

Hubert, M., Driessen, K. (2004). Fast and robust discriminant analysis. Computational Statistics \& Data Analysis, 45(2), 301-320.

Internetowy Podręcznik Statystyki, Analiza dyskryminacyjna. Pobrano z https://www.statsoft.p1/textbook/stathome_stat.html?https\%3A\%2F\%2Fwww.statsoft.pl\%2Ftextbook\%2Fstdiscan.html

Jajuga, K., and Walesiak, M. (2000). Standardization of data set under different measurement scales. In R. Decker, W. Gaul (Eds), Classification and information processing at the turn of the millennium (pp. 105-112). Berlin, Heidelberg: Springer-Verlag.

Krzyśko, M. (2004). Statystyka matematyczna. Poznań: Wydawnictwo Naukowe UAM.

Kukuła, K. (2016). Gospodarka odpadami komunalnymi w Polsce w roku 2015 w świetle wielowymiarowej analizy porównawczej. Acta Sci. Pol. Oeconomia, 15(4), 93-104.

McDonald, A. G., Bealey, W. J., Fowler, D. F., Dragosits, U., Skiba, U., Smith, R. I., Donovan, R. G., Brett, H. E., Hewitt, C. N., and Nemitz, E. N. (2007). Quantifying the effect of urban tree planting on concentrations and depositions of PM10 in two UK conurbations. Atmospheric Environment, 41(38), 8455-8467.

Nawrotek, E. (2017). Protection of Biodiversity vs New Legal Arrangements in the Field Protection of Green Areas and Wooded Lots. Studia Iuridica Lublinensia, 26(1), 315-330. 
Nowak, M. (2016). Ścieżki rowerowe w Polsce 2016. Takiego boomu jeszcze nie było. Pobrano z: http://www.portalsamorzadowy.pl/inwestycje/sciezki-rowerowe-w-polsce-2016-takiego-boomujeszcze-nie-bylo, $80522 . \mathrm{html}$

Onder, S., Dursun, S., Gezgin, S., and Demirbas, A. (2007). Determination of heavy metal pollution in grass and soil of city centre green areas. Polish Journal of Environmental Studies, 16(1), 145-154.

Ong, B. L. (2003). Green plot ratio: an ecological measure for architecture and urban planning. Landscape Urban Plan., 63(4), 197-211.

Saghapour, T., Moridpour, S., and Thompson, R. (2017). Measuring cycling accessibility in metropolitan areas. International Journal of Sustainable Transportation, 11(5), 381-394.

Sobolewski, M., and Sokołowski, A. (2017). Grupowanie metodą k-średnich z warunkiem spójności. Prace Naukowe Uniwersytetu Ekonomicznego we Wrocławiu, (468), 215-222.

Stanisz, A. (2007). Przystęny kurs statystyki, Tom 3. Kraków: Wydawnictwo StatSoft Polska.

WHO (2016). Global Urban Ambient Air Pollution Database. Pobrano z: http://www.who.int/phe/health_topics/outdoorair/databases/cities/en/

Walesiak, M. (2013). Zagadnienie doboru liczby klas w klasyfikacji spektralnej. Prace Naukowe Uniwersytetu Ekonomicznego we Wroctawiu, (278), 33-43.

Wyrwa, J. (2014). Inteligentna specjalizacja - nowa koncepcja rozwoju polskich regionów. Acta Sci. Pol. Oeconomia, 13(3), 143-154.

\section{KLASYFIKACJA POLSKICH MIAST NA PODSTAWIE WARUNKÓW ŚRODOWISKOWYCH I KOMUNIKACYJNYCH}

Streszczenie: Problemy związane z zanieczyszczeniem środowiska przyrodniczego dotyczą większości dużych miast w Polsce. Są one spowodowane głównie przez: transport, odpady komunalne, emisje z sektora komunalno-bytowego i z zakładów szczególnie uciążliwych dla otoczenia. Na podstawie danych dotyczących stanu i ochrony przyrody oraz transportu drogowego podjęto próbę podziału na grupy - różniące się cechami środowiskowymi - polskich miast na prawach powiatu. Do podziału wykorzystano analizę dyskryminacyjną. Najwyższa przeciętna wartość funkcji dyskryminacyjnej wskazała grupę o najkorzystniejszych warunkach przyrodniczych i społecznych. W kolejnych grupach zanieczyszczenie środowiska było coraz większe. Funkcje klasyfikacyjne analizy dyskryminacyjnej umożliwiły przydział poszczególnych miast do wyznaczonych grup. Analizę dyskryminacyjną można więc wykorzystać jako narzędzie wspomagające badanie stanu i ochrony środowiska w miastach. Celem tego opracowania jest identyfikacja zróżnicowania warunków przyrodniczo-środowiskowych i komunikacyjnych w miastach na prawach powiatu w Polsce.

Słowa kluczowe: analiza dyskryminacyjna, miasta na prawach powiatu, zanieczyszczenie środowiska. 